\title{
Hydrogeomorphic exploration of a local headwater stream in low mountainous environment following detailed field survey protocol (Mecsek Mountains, Hungary)
}

\author{
Szabolcs Ákos FÁBIÁN ${ }^{1}$, Péter KALMÁR ${ }^{1}$, Edina JÓZSA², Mateusz SOBUCKI ${ }^{3}$ \\ ${ }^{1}$ Department of Physical and Environmental Geography, Institute of Geography, University of Pécs, \\ Hungary \\ ${ }^{2}$ Doctoral School of Earth Sciences, University of Pécs, Hungary \\ ${ }^{3}$ Department of Geomorphology, Institute of Geography and Spatial Management, Jagiellonian \\ University in Cracow, Poland
}

Received 16 August 2016; Revised 12 December 2016; Accepted 13 December 2016

*Correspondence to: Szabolcs Ákos FÁBIÁN, e-mail: smafu@gamma.ttk.pte.hu

\begin{abstract}
Comprehensive field survey of the physiographic context and channel morphology is a key to distinguish characteristic hydrogeomorphic reaches of a watercourse. In this analysis field data were collected during seasonal campaigns following a field survey protocol developed in the Polish Carpathian Mountains. Complementary information was conducted from cartographic materials and digital elevation model to map diverse sections of the semi-natural Váralja Stream in the Eastern Mecsek Mountains. Geological, geomorphological and anthropogenic effects had to be considered as decisive factors in recent fluvial development, with emphasis on the sediment transport influenced by woody debris. A total of 12 hydrogeomorphic reaches were identified along the stream by interpreting the spatial arrangement of channel forms and analysing the characteristics of the watershed environment. The mapped reaches are connected with transitional zones of different length. Step systems are typical on the upper reach of the stream, but they were found to be the result of the geological composition and structure of the region. It was also proven that woody debris accumulations, made up of tree trunks, branches and roots have significant influence on the channel evolution of the Váralja stream. Even though the presented field survey instructions were field-tested in alpine catchments the conducted research confirmed the applicability of such workflow in low mountainous environment. Furthermore, the results on the hydrogeomorphic conditions of this small watershed with intense relief provide useful information for understanding the flash floods occurring in the region.
\end{abstract}

KEYWORDS

field survey protocol, channel morphology, geomorphometry, woody debris, Mecsek Mts. 


\section{Introduction and objectives}

More than 60 percent of cumulative length of the river network belongs to headwater streams, globally (Benda et al., 2005). They play a great role in feeding lowland rivers with water and sediments and also in connecting hillslopes and fluvial processes (Galia and Hradecky, 2014). Beyond their geomorphological importance the hydrological and ecological studies also concern the headwater streams. The hydrology of small catchments and interacting subsurface runoff and channelized flow were analysed to model hydrogeomorphic system of a steep watershed (Sidle et al., 2000). Forests have a great influence to development of headwater streams as living or dead dams (log and root) for small streams. Moreover, an intensive forestry and anthropogenic effects on land cover changes in mountainous environment can overmuch produce woody debris (WD) into channels. This process leads to a significant change in the sediment transport, longitudinal profile and the slope-channel system (Bilby and Ward, 1991; Harvey, 2001). These various hydrogeomorphic studies put headwater streams and watersheds in spotlight, recently.

Although the number of scientific papers concerning headwater (small) streams is growing a universal and simple definition of these features of the fluvial network is still missing (Benda et al., 2005). According to the widely-used Strahler's (1957) definition a headwater stream has a first or second order channel, but it has to be mentioned that the Horton-Strahler (HS) channel ordering system depends on the basic map resolution or the ephemeral character of the streams during field observation. It is self-explanatory that distinguishing between stream orders is difficult on the field, especially in mountainous environment under canopy cover. Other supposed criteria (i.e. slope gradient, watershed area, transition zone etc.) are strongly modified by local settings, moreover a few of them is also time dependent. Thus, a classical evaluation developing for low gradient rivers is not applicable to classify mountain channels into various environments (Galia and Hradecky, 2014).

The formation and transformation of river beds, fluvial landforms and the spatial and temporal changes of river channel patterns are indicative of the specific conditions of valley development and landscape evolutionary trends. Since the pioneering study of Leopold and Maddock (1953) to the present day a broad variety of channel classification systems were published almost yearly further investigating an ever-increasing number of parameters (Kaszowski and Krzemień, 1999; Lóczy et al., 2012; Grecu et al., 2014). However, the bed forms at the spatial scale of channel units in small streams were hardly studied (Grant et al., 1990). Only few studies deal with systematically exploring channel units in non-alluvial or semi-alluvial channels at headwater environment (Halwas and Church, 2002).

The available classification systems consider dozens of criteria. The most commonly analysed parameters are channel pattern (e.g. Leopold and Wolman, 1957; Montgomery and Buffington, 1997), stability (e.g. Schumm, 1963), the channel material and transported sediments (e.g. Raczkowska 1983) and the dominant processes (e.g. Kaszowski and Krzemień, 1999). Channel classifications and descriptions are typically based on the interpretation of aerial photographs, topographic and geological maps and hydrological data (Popov, 1969). Only few investigations supplemented the commonly applied laboratory methods with extensive fieldwork (Rudberg and Sundborg, 1975). Other approaches followed a standard guideline for channel analysis and mapping during the field survey (Krzemień, 1981; Kamykowska et al., 1999).

In this study, we adopt the latter methodology to explore the morphometric characteristics and channel development of a semi-natural headwater stream in a Hungarian low mountain environment. The scale of this channel classification methodology was changed as most of the Hungarian streams located in the hilly and low mountainous environments are small. Main advantages of this method (straightforward, comparable, repeatable and scale flexible) were utilized to get a complex and comprehensive system to explore hydrogeomorphology of the analysed stream channel. Headwater streams and watersheds have been hardly studied in Hungary, it was the most easily acceptable standard method based on field observation. 
There is a scientific need to analyse these small watersheds with headwater streams, because of the increasing number of extreme hydrometeorologic events in the last decade in Hungary (Horváth, 2005, 2015). The more frequently occurring flash floods require extensive research on these previously neglected watersheds and streams (Czigány et al., 2010). Even though, many other factors influence the occurrence of flash floods (Czigány et al., 2011), the topography and the channels draining the water are considered amongst the most important. Field observations on these small watersheds, a channelreach classification and analysis of the spatiotemporal pattern of the landscape evolution is essential to the understanding and proper management of future flash floods.

The aim of this study was to evaluate the morphometric characteristics of a semi-natural headwater stream and explore the applicability of a standard Polish channel mapping method in a Hungarian low mountainous environment. For this purpose, detailed information was recorded about the channel parameters and forms on the standard register form of the field survey protocol, moreover the forms were mapped using GPS devices and recorded on photos. The gathered information supplemented with geological and GIS-based data was interpreted to delineate characteristic reaches of the Varalja stream according to the method of Kamykowska et al. (1999). The research also focused on exploring the factors influencing the channelreach morphology of the studied sections.

A secondary objective of the study was to present the scientific problems arising in case of the hydrogeomorphic interpretation of headwater streams in low mountains for wider and international professional audience was also aimed.

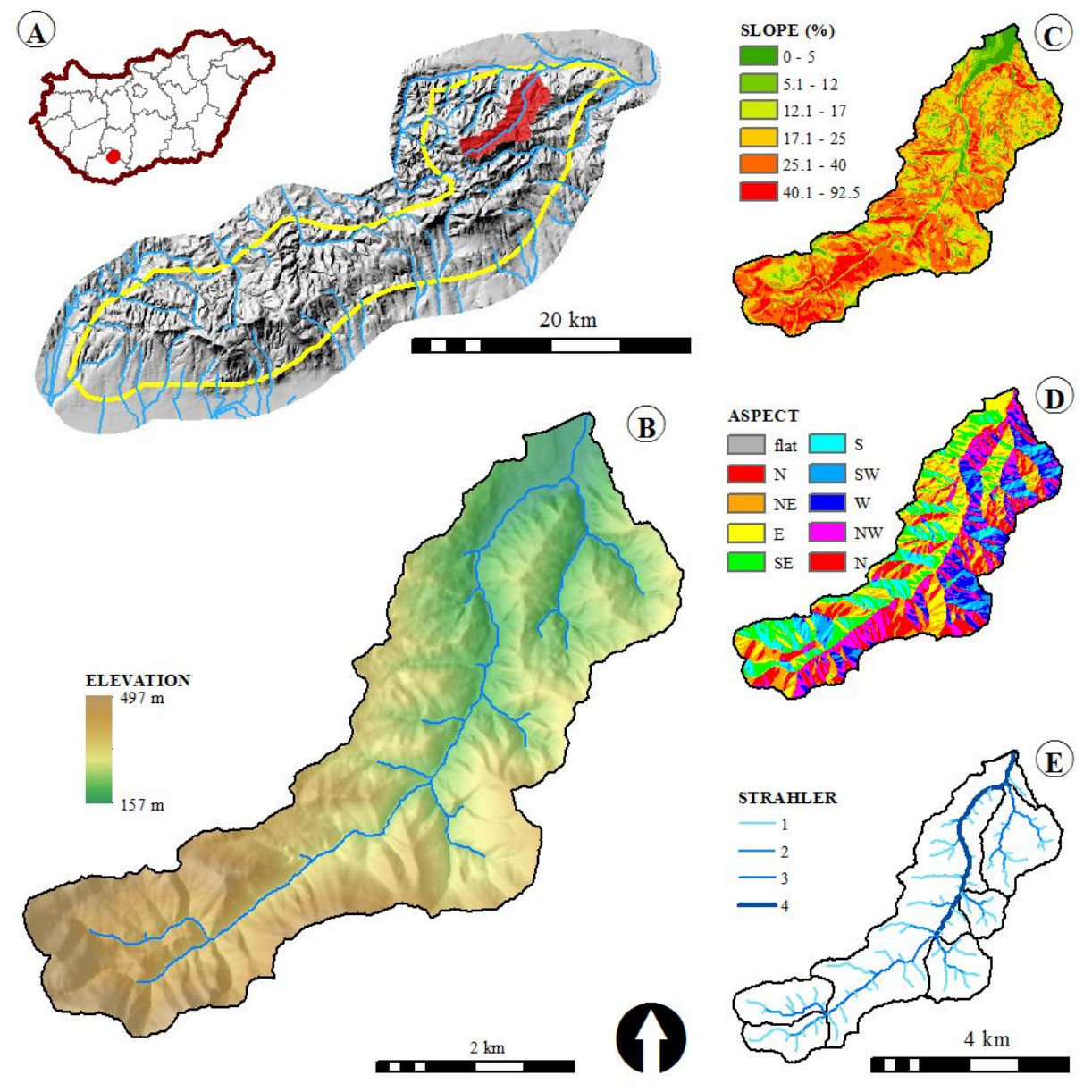

Figure 1 Location (A) and topography (B) of study area, slope (C) and aspect map (D), and ordered channel network (E) of the Váralja watershed (edited by E. Józsa). 


\section{Study area description}

The studied Váralja stream is located in the northern part of the Eastern Mecsek Mountains, in Tolna County (Fig. 1). The watercourse joins the Danube water system through watercourses of local significance. The elongated catchment area of the stream covers about $15 \mathrm{~km}^{2}$, the coordinates of the outlet: $46^{\circ} 16^{\prime} 35.2^{\prime \prime} \mathrm{N}, 18^{\circ} 26^{\prime} 36.9^{\prime \prime} \mathrm{E}$. It should be noted that the watershed is uncertain around the outlet reach (cf. Table 1 and online web GIS application of HISSTWMD': http://ddvir.ddvizig.hu: 8000/ddvir/flex/ddvir.html\#). The second highest peak of the Eastern Mecsek Mountains (Dobogó, $593.7 \mathrm{~m}$ ) is situated at the western boundary of the basin. Gradually lowering ridges and interfluves are lined up symmetrically on both sides of the valley, e.g. Szamár Hill, Szószék, Csalán Hill, Nagy Hill, Közép Hill, Váralja Hill, Szarvas Hill. The mean elevation of the basin is $313 \mathrm{~m}$ above sea level.

The area is minutely dissected, in the upper valley relative relief is $200 \mathrm{~m} / \mathrm{km}^{2}$, while absolute relief reaches $446 \mathrm{~m}$. Both the main channel and the smaller tributaries are deeply incised, therefore steep valley sides up to 5 to $10 \mathrm{~m}$ can be found in the basin. Analysing DEM to classify the slope gradient thresholds for erosion the $62.56 \%, 43.83 \%$ and $14.25 \%$ of the total area belongs to the slopes with $>20 \%, 5-20 \%$ and $<10 \%$ gradient, respectively.

Table 1 Morphometric parameters of the Váralja stream basin based on DEM and land cover characteristics from CLC2012.

\begin{tabular}{lr}
\hline Parameters & Value and unit \\
\hline Catchment area (A) & $14.9 \mathrm{~km}^{2}$ \\
Maximum catchment basin length (L) & $10.4 \mathrm{~km}$ \\
Catchment shape index (C) & 0.3 \\
Form factor (F) & 0.1 \\
Valley system length & $40.9 \mathrm{~km}$ \\
Drainage density & $3.0 \mathrm{~km} / \mathrm{km}^{2}$ \\
Integration index & $2.7 \mathrm{~km} / \mathrm{km}^{2}$ \\
Forested area & $11.5 \mathrm{~km}^{2}$ \\
Woodiness index & $76.7 \%$ \\
Grassland area & $2.0 \mathrm{~km}^{2}$ \\
Arable land area & $1.0 \mathrm{~km}^{2}$ \\
\hline
\end{tabular}

${ }^{1}$ Hydrological Information System of the South-Transdanubian Water Management Directorate
Although c. 2/3 of the watershed has steeper slopes and erosional position, the moderately sloping transitional position is also remarkable. The basin is nearly symmetric; the proportions of northern and southern slopes are similar in the region (Table 1).

The bedrock of the Eastern Mecsek Mountains is dominated largely by Jurassic rocks with a lesser extent of Cretaceous - in particularly Early Cretaceous - formations (Fig. 2, Table 2). In the region Early Jurassic (Liassic) coal seams are found, and their excavation - besides its economic significance - led to the geologic exploration of a syncline structure (Haas, 2012). The basalt volcanism in the Cretaceous resulted in the pillow lava forms of the Márévár valley, while the subvolcanic activities produced phonolite in the region of the Szamár Hill (Lehmann, 1995). In the study area it only occurs on the south-eastern slopes of the valley head; not in the form of outcrops, but covered by debris.

Most of the rocks are not purely limestones, but calcareous, siliceous, sandy, silty limestones or marls, thus they are hardly or not at all karstified. As a consequence, the valley system is more diversified and developed compared to the Western Mecsek Mountains, and here the karst features are also missing. However, the numerous appearances of travertines prove the relatively rich carbonate content in the groundwater.

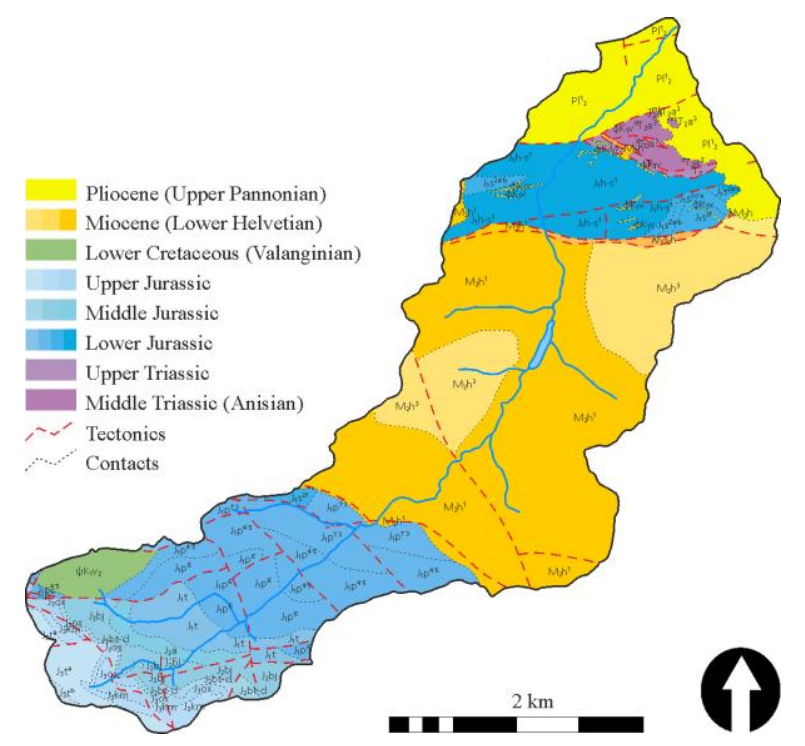

Figure 2 Revised geologic map of the basin (edited by P. Kalmár and E. Józsa). 
Hydrogeomorphic exploration of a local headwater stream in low mountainous environment following detailed field survey protocol (Mecsek Mountains, Hungary)

Table 2 Geology of the morphostructural sections of the Váralja stream based on the geological map at scale 1:25 000 (former key) and Gyalog (ed.) 1996, 2005 and Kercsmár et al. 2015

\begin{tabular}{|c|c|c|c|c|}
\hline $\begin{array}{c}\text { (revised key } \\
\text { and } c f . \text { Fig. 3) } \\
\text { No. }\end{array}$ & Geological formations & $\begin{array}{l}\text { Former } \\
\text { key }\end{array}$ & $\begin{array}{l}\text { Revised } \\
\text { key }\end{array}$ & Characteristic rocks and sediments \\
\hline G1 & $\begin{array}{l}\text { Fonyászó, Kisújbánya and } \\
\text { Várkonyi Limestone Fm }\end{array}$ & $\begin{array}{l}\mathrm{J}_{3} \mathrm{Ox} \\
\mathrm{J}_{3} \mathrm{~km}\end{array}$ & $\begin{array}{l}\mathrm{f}_{3} \\
\mathrm{k} \mathrm{J}_{3} \\
\mathrm{v} \mathrm{J}_{3}\end{array}$ & $\begin{array}{l}\text { siliceous limestone and radiolarite, nodular, cherty } \\
\text { limestone }\end{array}$ \\
\hline G2 & $\begin{array}{l}\text { Dobogó Calcareous Marl } \\
\text { Fm and Óbánya } \\
\text { Limestone Fm }\end{array}$ & $\mathrm{J}_{2}{ }^{\mathrm{bt}-\mathrm{cl}}$ & $\begin{array}{l}d_{J_{2}} \\
o_{J_{2}}\end{array}$ & $\begin{array}{l}\text { marl (with limestone nodules), calcareous marl and } \\
\text { nodular limestone, clay marl and siliceous calcareous marl }\end{array}$ \\
\hline G3 & $\begin{array}{l}\text { Komló Calcareous Marl } \\
\text { Fm }\end{array}$ & $\mathrm{J}_{2} \mathrm{bj}$ & $\mathrm{km}_{\mathrm{J}_{1-2}}$ & $\begin{array}{l}\text { grey, mottled, bioturbated, ammonite-bearing silty marl, } \\
\text { calcareous marl and clayey limestone }\end{array}$ \\
\hline G4 & $\begin{array}{l}\text { Komló Calcareous Marl } \\
\text { Fm }\end{array}$ & $\mathrm{J}_{2} \mathrm{a}$ & $\mathrm{km}_{\mathrm{J}_{1-2}}$ & laminated marl and clay marl \\
\hline G5 & $\begin{array}{l}\text { Óbánya Siltstone Fm and } \\
\text { Komló Calcareous Marl } \\
\text { Fm }\end{array}$ & $\mathrm{J}_{1} \mathrm{t}$ & $\mathrm{ój}_{1}$ & sandstone, siltstone and spotted marl \\
\hline G6 & $\begin{array}{l}\text { Kecskehát Limestone } \mathrm{F} \\
\text { mand Mecseknádasd } \\
\text { Sandstone Fm }\end{array}$ & $\begin{array}{l}J_{1} p^{1-3} \\
J_{1} p^{4-5} \\
J_{1} p^{6}\end{array}$ & $\mathrm{kh}_{\mathrm{J}_{1}}$ & $\begin{array}{l}\text { siliceous crinoidal limestone, siliceous sandstone and } \\
\text { breccia complex }\end{array}$ \\
\hline G7 & $\begin{array}{l}\text { Szászvár Fm and Szászvár } \\
\text { Member (Gyulakeszi } \\
\text { Rhyolite Tuff) }\end{array}$ & $\begin{array}{l}\mathrm{M}_{2} \mathrm{~h}^{1} \\
\mathrm{M}_{2} \mathrm{~h}^{3} \\
\left(\lambda \mathrm{M}_{2} \mathrm{~h}\right)\end{array}$ & $\begin{array}{l}{ }^{\mathrm{sz}} \mathrm{Me}-\mathrm{O} \\
{ }_{\mathrm{s}} \mathrm{Me}-\mathrm{O} \\
\left({ }^{\mathrm{g}} \mathrm{Mo}\right)\end{array}$ & $\begin{array}{l}\text { variegated siltstone, sand, sandstone, gravel and } \\
\text { conglomerate with rhyolite tuff intercalations }\end{array}$ \\
\hline G8 & Mecsek Coal Fm & $\mathrm{J}_{1} \mathrm{~h}-\mathrm{s}^{1}$ & ${ }^{\mathrm{mk}} \mathrm{T}_{3}-\mathrm{J}_{1}$ & $\begin{array}{l}\text { sandstone, foliated clay, and claystone, black coal } \\
\text { intercalations }\end{array}$ \\
\hline G9 & $\begin{array}{l}\text { Mecsekjános Basalt Fm } \\
\text { and } \\
\text { SzamárhegyPhonolite } \\
\text { Member }\end{array}$ & $\psi K_{1} \mathrm{~V}$ & ${ }_{\mathrm{m}_{\mathrm{sz}} \mathrm{K}_{1}}^{\mathrm{m}_{\mathrm{K}}}$ & $\begin{array}{l}\text { subvolcanic and submarine volcanic complex, alkali basalt } \\
\text { and phonolite }\end{array}$ \\
\hline G10 & $\begin{array}{lll}\begin{array}{l}\text { Dunántúl } \\
\text { (former }\end{array} & \text { Fm } & \begin{array}{l}\text { group } \\
\text { Upper }\end{array} \\
\text { Pannonian) } & & \end{array}$ & $\mathrm{PI}_{2}^{1}$ & ${ }^{\mathrm{D}} \mathrm{Pa}_{2}$ & fluvial, lacustrine and paludal sand and clay \\
\hline
\end{tabular}

The climatic conditions of the study area are not significantly different from the average values of Hungary. The annual sunshine duration is 20402060 hours, while annual mean temperature is $9.5-$ $10^{\circ} \mathrm{C}$, closer to the peaks only $9^{\circ} \mathrm{C}$. Due to the low mountain environment the annual amount of precipitation is above the national average, $680-800$ $\mathrm{mm}$. Precipitation maxima typically occur in early summer or autumn, but with the decrease in the number of days with precipitation intense rainfall events are becoming more frequent. According to the classification by Péczely (1979) the climate of the studied catchment is moderately cool moderately wet and cool - moderately wet.

Stream discharge is based on the information available from the HISSTWMD. Annual mean discharge is $0.066 \mathrm{~m}^{3} / \mathrm{s}$ at the outlet and $0.012 \mathrm{~m}^{3} / \mathrm{s}$ at the confluence of the two headwaters $(8,420 \mathrm{~m}$ from the outlet). The total length of the stream is $10,131 \mathrm{~m}$ and the elevation drop is $369 \mathrm{~m}$. In 1977 three water reservoirs were constructed on the stream for recreation and flood protection purposes 
on the section between $3980 \mathrm{~m}$ to $4640 \mathrm{~m}$ from the outlet. In spite of that, the calculated flash flood risk of the watershed is 4 and 5 in a 1-6 ranged scale (Czigány et al., 2010).

A large part, $76.7 \%$, of the area is covered with forests, dominantly oak-hornbeam associations, on the higher regions with northern exposure beech stands also appear. On the valley bottom hydrophilic alder species occur. The lower parts of the basin belong to the outskirts of the village Váralja with mainly arable and grassland cultivation.

\section{Materials and methods}

The research objectives required extensive field surveys to map channel characteristics and auxiliary information from expert-based topographical and geological maps to interpret the field notes. The primary review of the morphological and geological characteristics of the study area was based on the 1:10 000 scale unified Hungarian topographic maps and geological maps at different scales (1:10 000 and 1:25000). A contour-based digital elevation model with $5 \mathrm{~m}$ horizontal resolution from the FÖMI (National Institute of Geodesy, Cartography and Remote Sensing) was used to represent the topography of the drainage area and automatically derive hydrogeomorphic parameters and basin metrics. Basic hydrological information on the Váralja stream were also available from the webbased HISSTWMD.

The channel mapping and description methodology consisted of the integrated classification system introduced by Krzemien and research group (Kaszowski \& Krzemień, 1999; Kamykowska et al., 1999). This mapping technique was successfully adopted in different geomorphologic settings, e.g.: high mountains and their foreland (Krzemień, 2003), glacial trough (Krzemień, 1999), following catchment capture (Chełmicki \& Krzemień, 1999), Holocene volcanism influence (Krzemień, 2004), following extreme and flash floods in middle mountains (Izmaiłow et al., 2006; Gorczyca, 2007), river training (Korpak, 2007), lowland late-glacial system (Angiel, 1999). Therefore, it was expected to provide correct results for the investigated basin. The morphometric and hydrogeomorphic survey was carried out following the guideline by Kamykowska et al. (1999), recording the information in a specifically designed report, including: preliminary information (1), description of the channel (2), hydrogeomorphic characteristics of the stream (3), hydrometeorological conditions of the research period (4) and morphometry of the river drainage basin (5) (Krzemien et al., 2015). The full description of this method can be found in the above cited papers, discussion of the steps in detail is out of the scope of the present study.

The significant landmarks, characteristic landforms and geologic features were mapped along the channel using a Dakota 20 Garmin handheld GPS. Field observations, notes and photos about the channel and valley forms and materials were gathered and arranged according to the instructions. A total of 150 pebbles were randomly collected at ten characteristic profiles of six sections and all three axes were measured by ruler. The width and depth of the channel were also measured at those points. Zingg's shape index (Zingg, 1935) was computed to analyse and classify roundness of transported gravels. The particle size index based on the nominal diameter $D_{n}=(a \cdot b \cdot c)^{1 / 3}$ were calculated for every measured cross section.

\section{Results and discussion}

The hydrogeomorphic sections of the stream were delineated in three steps. First by analysing the detailed topographic map in scale 1:10 000, thereafter deducing from the geological maps, and finally mapping the sections based on the modified version of field survey methodology of Kamykowska et al. (1999). Based on the characteristic changes in the topography 8 , according to the geologic units 10 (Table 2) and interpreting the results of the channel mapping technique 12 reaches were separated on the stream (Fig. 3). The reaches delineated according to the topographic map and the other two methods rarely match. The reason for this is mainly that the map contains little information on the terrain characteristics, the available scale is not detailed enough; the contour lines representing the topography and the drawing of the watercourses are generalized. 

(Mecsek Mountains, Hungary)
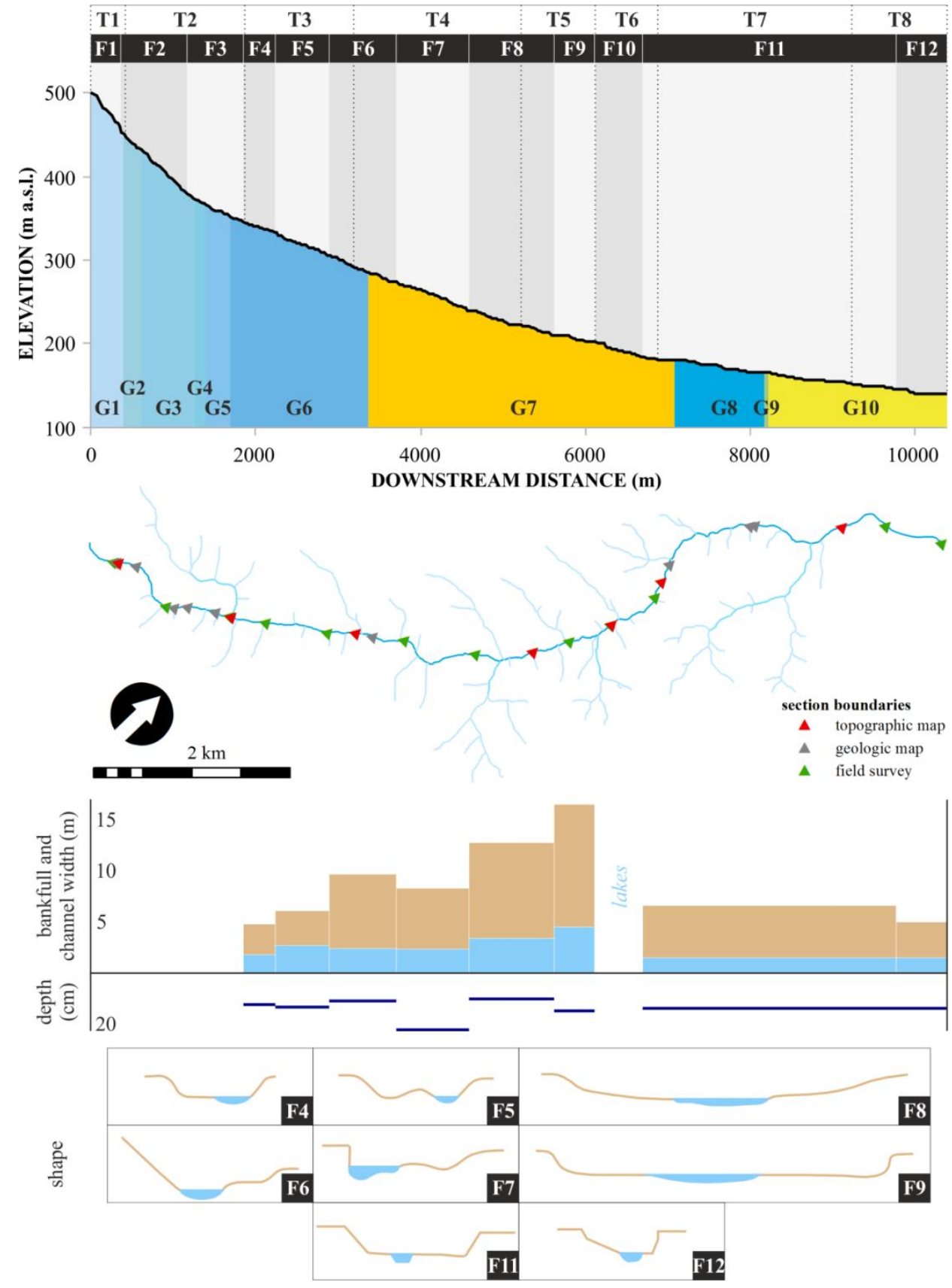

Figure 3 Long profile and sections of the Váralja stream. T1-T8 based on topographic map, F1-F12 according to field survey, G1-G10 by geologic units.

On the upper sections of the stream, where the steps and step systems are decisive, the reaches based on the topography and geology, show many similarities. On the lower stretch the stream reaches the bedrock only locally, so the geological conditions are less important in the development of the channel, accumulation forms are getting typical, e.g. woody debris and bars. The field observations and the above-mentioned field reports provided sufficient information for the most accurate delineation of section boundaries. Section F1-F2, as the steepest reach with hollows differs significantly since the channel has a colluvial character and some bedrock steps. Section F3 is characterised by bedrock channel and step-pool system and an asymmetric steep valley profile due to the 
combination of the geological settings (Fig. 1) with higher discharge. Therefore, in these sections channels can hardly be identified. Similar slope process dominated section was mapped at F5 with narrow $V$ shaped valley and outcrop step-pool reaches after the confluence $(1.9 \mathrm{~km})$ of two source channels.

The mapped channel forms are summarized in Table 3. Based on the number and size of the occurring landforms the following characteristics can be highlighted. Steps and step-pool systems were found along the total length of the stream. The number and size of these features widely vary, while their shape and layering show similarities (Photo 1). Relative to the river course the pattern of the steps is transverse or oblique and matches the strata dip. The size of the steps varies from $5-10 \mathrm{~cm}$ to $150 \mathrm{~cm}$; the most frequent values are $20-30 \mathrm{~cm}$.

The upper part of the steps is a hard, flat surface, and downstream the steps there are small pools where finer bedload is accumulating. In this finer sediment $5-10 \mathrm{~cm}$ or in some cases even 50 $\mathrm{cm}$ deep pools were formed. On the lower section, below the lakes the stream is flowing across young (Miocene, Pliocene) loose sediments (Fig. 2, Table 2). An interesting phenomenon here is that the barriers formed by tree roots are leading to hydrogeomorphic conditions similar to what the steps cause (Photo 2). Pools with $30-40 \mathrm{~cm}$ depth and $2-3 \mathrm{~m}$ width also occur on this part.

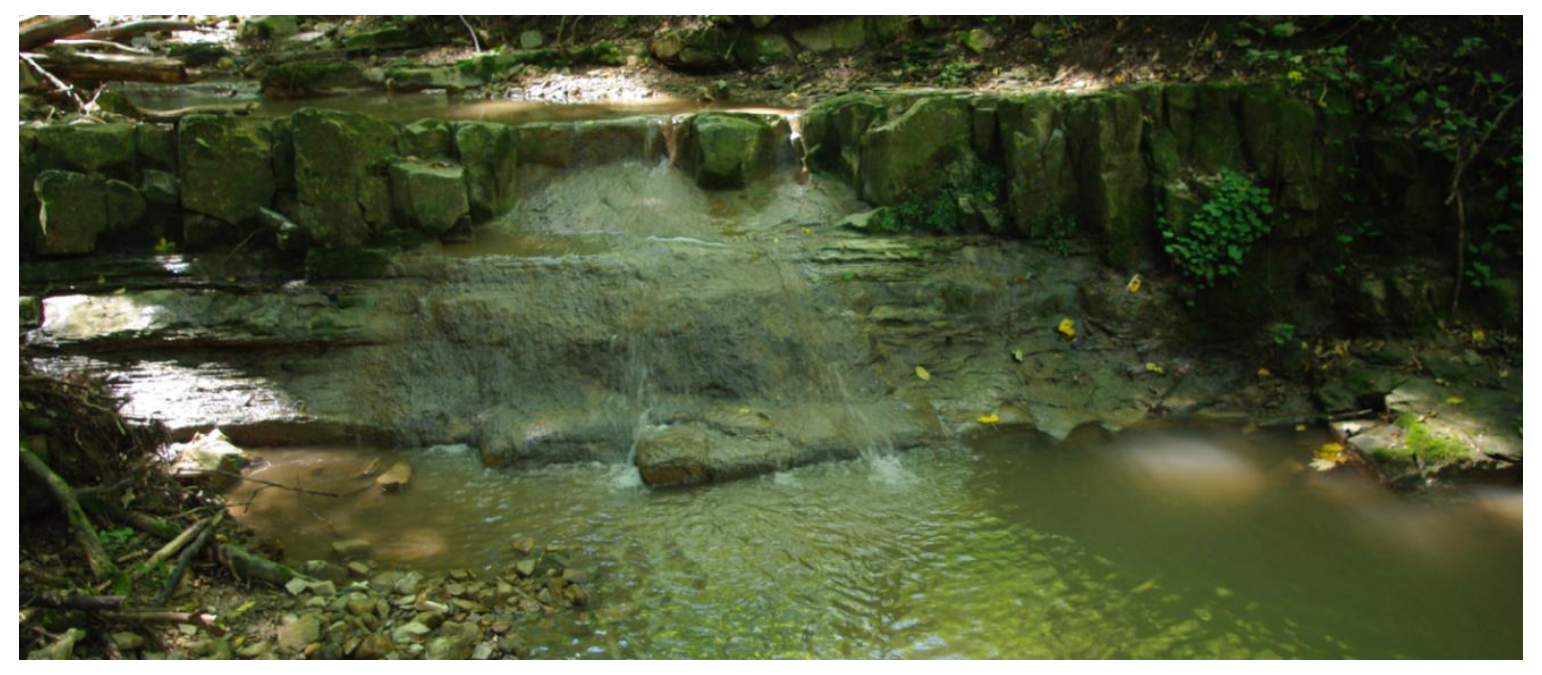

Photo 1 Steps on the stream (Photo by P. Kalmár 2014)

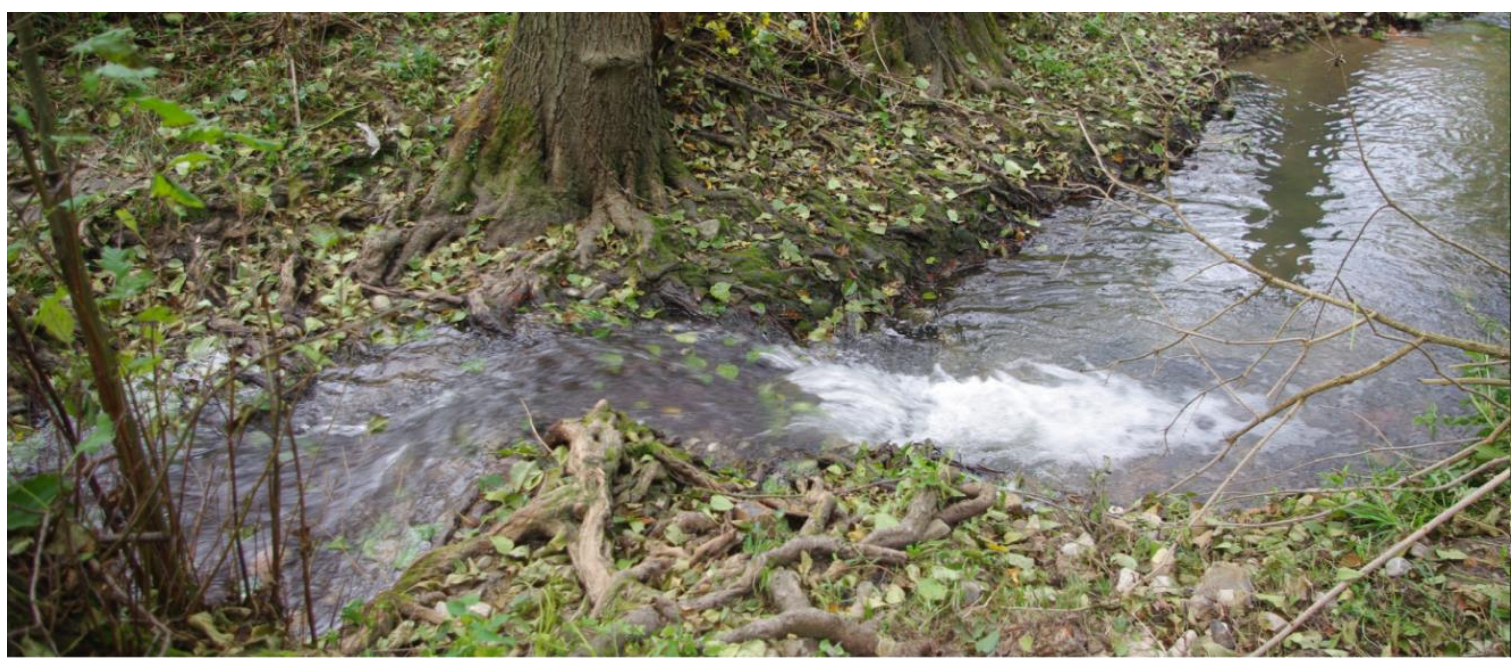

Photo 2 Higher energy part at tree roots and the formed erosion hole (Photo by P. Kalmár 2014) 
Riffles were mapped on the middle and lower sections of the stream, but channel unit distinctiveness was poor compared to downstream sections. The morphology showed transitional character between plane bed and pool-riffle semialluvial channel-reaches. A common phenomenon is that the larger blocks transported by mass movements from the valley sides is mixed with branches and leaves, and creates dams. In case of intense rainfalls likely these stone blocks with a diameter above $30 \mathrm{~cm}$ are also entrained and the material is becoming more classified, which promote the formation of riffles and rapids (Lóczy, 2012).

The banks appear in diverse forms. On the upper sections (F1-F2) they are not typical; the valley is more like a gully with indefinite bed (cf. Fig. 1E). 20-40 $\mathrm{cm}$ high banks occur on the section $\mathrm{F3}$, as the bedrock outcrops are getting more frequent and compelling the stream to change direction, thus lateral erosion becomes predominant. On the sections F4-F7 vertical erosion is intense, $1-1.5 \mathrm{~m}$ high banks can be observed (Photo 3). Below the F8 section the valley is getting wider, lateral erosion is becoming the typical process and alluvial character also occurs. These can be large forms (relative to the studied stream), even 10-15 m long and 5-6 m wide. Bars were found all along the stream except from upper sections (F1-F4), although with varying materials and sizes. On the middle sections (F6-F7) they are formed from the finer sediments deposited downstream the steps and upstream WD dams and boulders. These channel-reaches have a "forced alluvial" character (Montgomery and Buffington, 1997) with some small semi-alluvial forms. These bars are usually smaller $(50 \mathrm{~cm}$ long and $40 \mathrm{~cm}$ wide on average) and temporary features, displaced or destroyed by increased discharges. On the lower sections, we observed point bars built up from cobbles that can have a diameter of even $10-15 \mathrm{~cm}$ (Photo 4). Smaller islands appear on the sections F6-F7 and F9, where between the separated channels they are often only temporarily surrounded with water, in case of higher water levels. They can reach 15-20 $\mathrm{m}$ length and 6-8 $\mathrm{m}$ width.

According to Zingg's classes the 44, 27, 19 and $10 \%$ of collected pebbles has discoidal, bladed, rods and spherical shape, respectively. A relationship between the channel length and the shape was not detectable. Though, a not too strong relationship $\left(R^{2}=0.41\right)$ exists in the resulting linear trend: $D_{n}=0.52 C_{w}+4.2$, where $C_{w}$ (in meters) is channel width. On the other hand, no relationship could be identified between particle size index and channel depth or between the computed average channel gradient and particle size index $\left(\mathrm{R}^{2}<0.1\right)$. The ratio of particle size index to water depth $\left(D / D_{n}\right)$ is above 1.0 in every section with one exception at F7. As other small channels this also has a higher relative roughness.
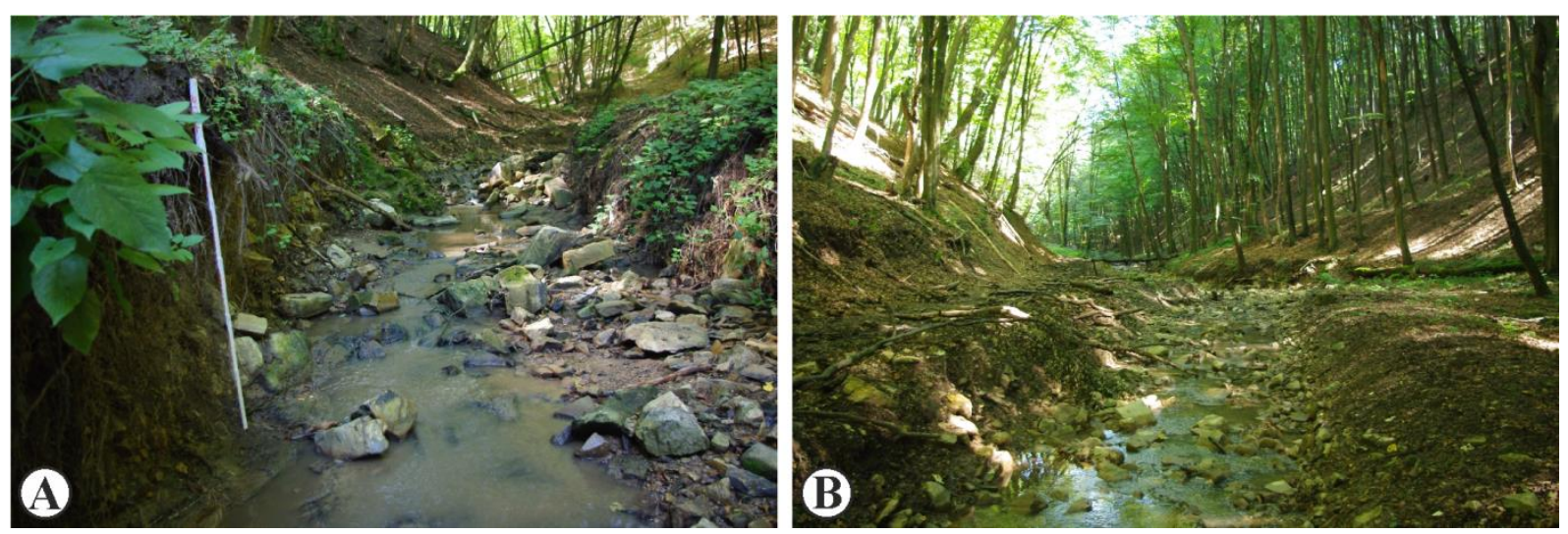

Photo 3 Examples of deeper vertical erosion on sections F4-F7 (Photo by P. Kalmár 2014) 


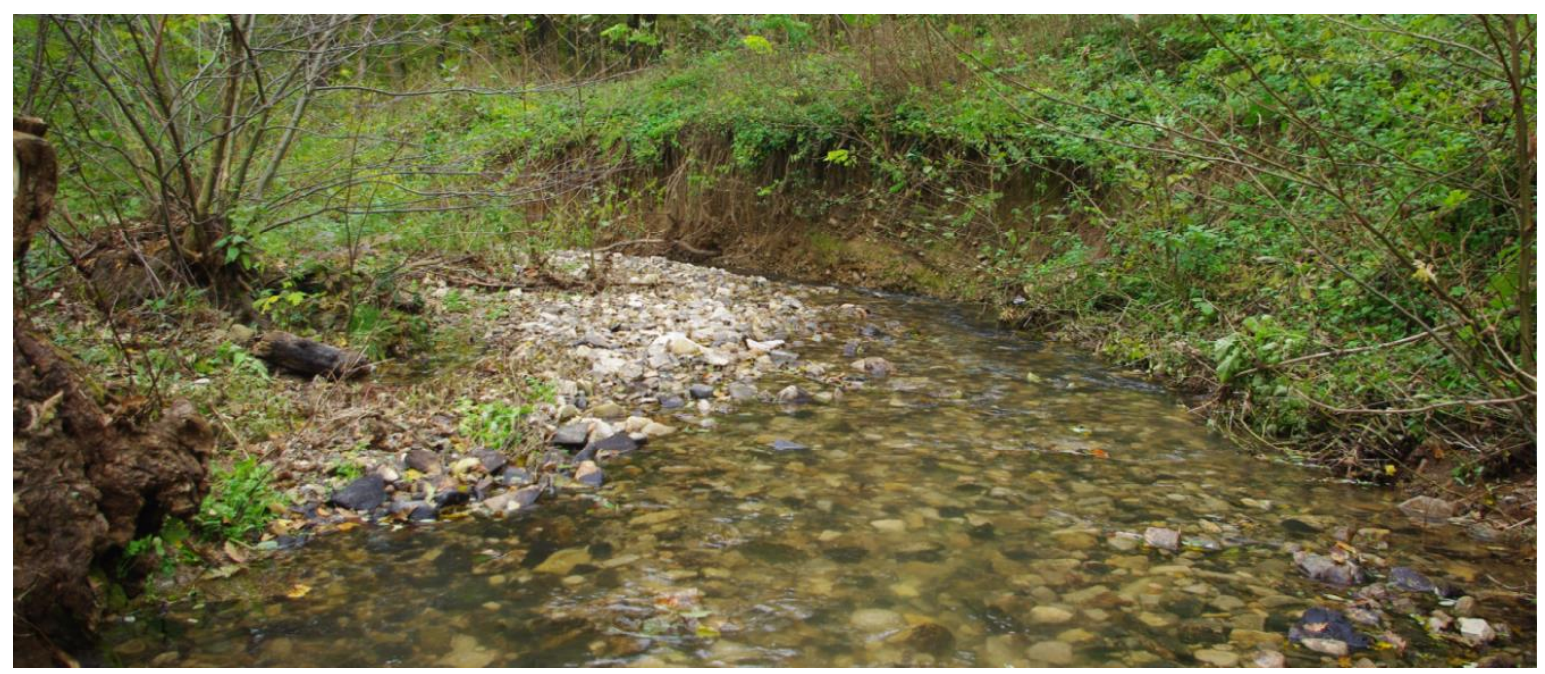

Photo 4 Cobble bar and cut bank on section F11 (Photo by P. Kalmár 2014)

Although it is not part of the applied method (Kamykowska et al., 1999) to analyse woody debris (WD), but as three quarters of the basin are covered by forests, the tree trunks and branches have a significant influence on landscape evolution. There are two sources of WD: the naturally decaying vegetation and forestry waste, which is getting to the valley bottom from the steep slopes of the higher hills. These materials accumulate in the main channel and jammed to form dams, the larger of which can exist possibly for longer periods (even years), as we observed channel relocations due to these WD dams (Photo 5). These woody materials have a significant impact on the flora and fauna of the stream, and they also alter the formation of natural transition zones between the drainage basin and the watercourse (Bilby and Ward, 1991). Based on the observed woody debris and dams, on various reaches of the stream only great floods are considered to be adequate for further transport.

During the last decade, the years 2010 and 2014 were extremely humid, as the annual precipitation has exceeded $900 \mathrm{~mm}$. The highest monthly total precipitation at Váralja $(255.4 \mathrm{~mm})$ recorded during May of 2010. This humid period is supposed to be responsible for recent WD transport and dam formation.

The village of the same name and the cultivated valley bottom are at the lowest sections of the Váralja stream, so channel regulation and flood control works were carried out. The watercourse was artificially deepened and gabions were placed for protecting the banks (Photo 6). Even though these anthropogenic structures are not preventing the natural transformation of the stream, they considerably slow down the bed-forming processes. However, the effect of the flash floods is the strongest in this area, as a result of the elongated catchment area and the significant decrease of elevation drop in this section (Fig. 1).

The hydrogeomorphic characteristics explored in this study reveal that the development of each stream section and their spatial order is not closely related to the low mountain environment of the basin. The 12 sections identified based on the bed and valley forms are not separated by clear boundaries, but they are connected with transitional zones. In fact, the so typical step systems were not formed by the stream, but they are a result of the geological composition and structure of the region. The sections with knickpoints and the steep, convex slopes are evidence for the recent uplift of the Eastern Mecsek Mountains (Dunkl, 1992). These steps were only exposed by the stream and the processes forming the valley, which means that the step systems control the hydrogeomorphic dynamics of the watercourse along these sections.

Even though the presented method has been developed for mountainous and alpine environments, our study proved its applicability in a low mountainous region as well. In our opinion, the decisive condition for the application of this method is not the terrain characteristics, but the size of the analysed watercourse. 

(Mecsek Mountains, Hungary)
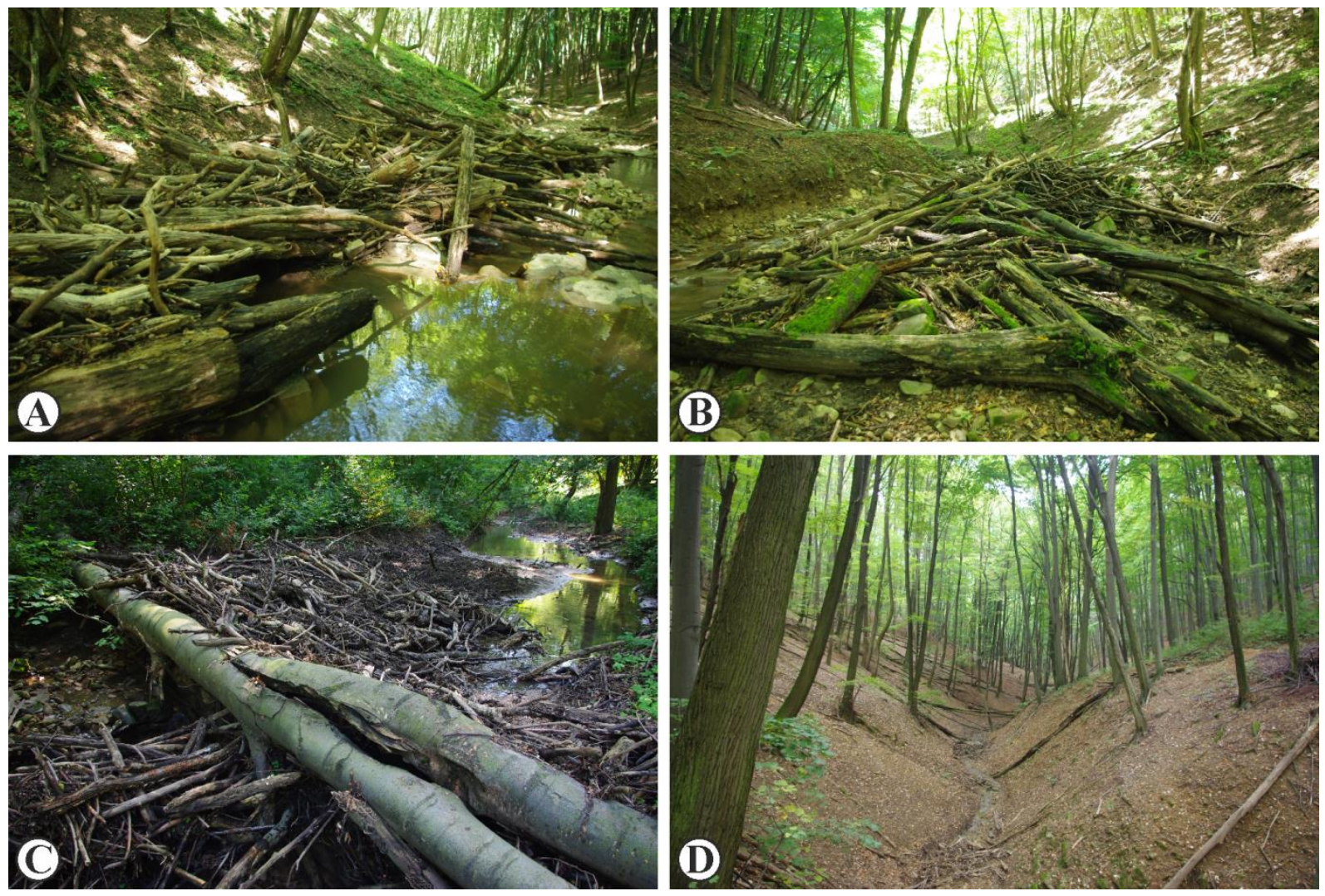

Photo 5 Woody debris in the channel (A - left sided; B - middle bedded; $C$ - dam type) and the source of the material (D)

(Photo by P. Kalmár 2014)

Table 3 Characteristic size of the mapped channel forms in the Váralja watershed

\begin{tabular}{ccccccccccc}
\hline \multirow{2}{*}{ No. } & \multicolumn{2}{c}{ Steps } & \multicolumn{2}{c}{ Pools } & \multicolumn{2}{c}{ Cut bank } & \multicolumn{2}{c}{ Bar \& island } & \multicolumn{2}{c}{ Woody debris } \\
\cline { 2 - 10 } & $\mathbf{n}$ & Height & $\mathbf{n}$ & Depth & $\mathbf{n}$ & Height & $\mathbf{n}$ & Length & $\mathbf{n}$ & Length \\
\hline F1 & - & - & - & - & - & - & - & - & - & - \\
F2 & 8 & $0.3 \mathrm{~m}$ & 4 & $0.1 \mathrm{~m}$ & - & - & - & - & $10+$ & $2 \mathrm{~m}$ \\
F3 & 10 & $0.25 \mathrm{~m}$ & 7 & $0.2 \mathrm{~m}$ & 6 & $0.5 \mathrm{~m}$ & - & - & 4 & $1 \mathrm{~m}$ \\
F4 & 9 & $0.4 \mathrm{~m}$ & 5 & $0.3 \mathrm{~m}$ & 10 & $0.8 \mathrm{~m}$ & 3 & $2 \mathrm{~m}$ & 4 & $2 \mathrm{~m}$ \\
F5 & $20+$ & $0.45 \mathrm{~m}$ & $10+$ & $0.3 \mathrm{~m}$ & 8 & $0.8 \mathrm{~m}$ & 2 & $1 \mathrm{~m}$ & 6 & $4 \mathrm{~m}$ \\
F6 & 5 & $0.2 \mathrm{~m}$ & 3 & $0.2 \mathrm{~m}$ & $10+$ & $1,2 \mathrm{~m}$ & 2 & $6 \mathrm{~m}$ & $10+$ & $8 \mathrm{~m}$ \\
F7 & 1 & $0.15 \mathrm{~m}$ & 2 & $0.4 \mathrm{~m}$ & 6 & $1,2 \mathrm{~m}$ & 4 & $6 \mathrm{~m}$ & 8 & $6 \mathrm{~m}$ \\
F8 & - & - & 2 & $0.3 \mathrm{~m}$ & 2 & $0.4 \mathrm{~m}$ & 6 & $4 \mathrm{~m}$ & 4 & $2 \mathrm{~m}$ \\
F9 & - & - & 4 & $0.5 \mathrm{~m}$ & 8 & $1 \mathrm{~m}$ & 6 & $4 \mathrm{~m}$ & 4 & $1 \mathrm{~m}$ \\
F10 & - & - & - & - & - & - & - & - & - & - \\
F11 & 2 & $0.2 \mathrm{~m}$ & - & - & $10+$ & $2 \mathrm{~m}$ & 4 & $2 \mathrm{~m}$ & 1 & $1 \mathrm{~m}$ \\
F12 & - & - & - & - & 4 & $2 \mathrm{~m}$ & - & - & - & - \\
\hline
\end{tabular}



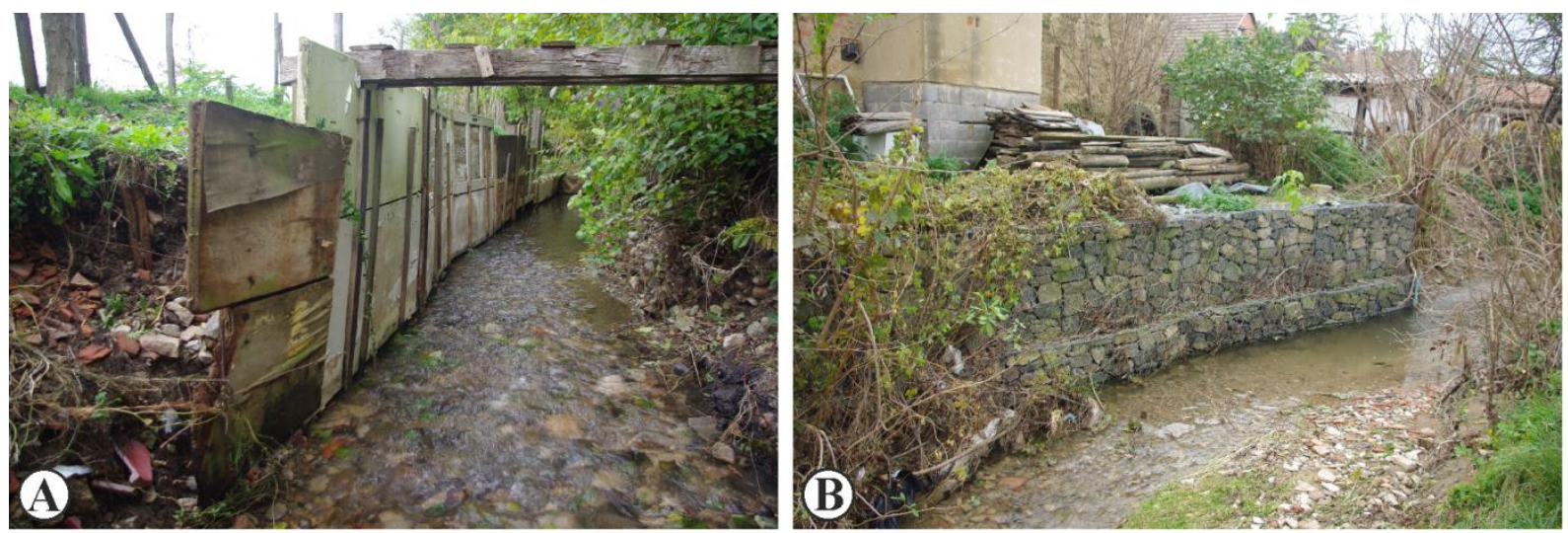

Photo 6 Simple makeshift bank revetment (A) and gabion protection (B) of banks (Photo by P. Kalmár 2014)

\section{Conclusions}

In the present study, we explored the applicability of the channel classification method by Kaszowski and Krzemień (1999) and Kamykowska et al. (1999) in the case of a headwater stream drainage basin in Southern Hungary. Based on the available topographic and geologic maps and the GIS-based morphometric parameters we gathered preliminary information about the study area. During several field surveys, we recorded the parameters of channel and valley forms according to the guidelines of the methodology presented and mapped their location using a handheld GPS device along the entire stretch of the Váralja stream. Due to the extensive forest cover the vegetation plays a key role in river bed evolution and recent development of the valley. For this reason, we concluded that it is necessary to supplement the report with recording the changes in the channel caused by WD.

Taking into consideration the geological and anthropogenic factors influencing the characteristic landforms and valley evolution we delineated 12 dynamically distinct sections with transitional zones. For the upper section of the stream (to the end of the Farkas ditch, F1-F3) the presence of steps, step systems are specific. The occurrence of WD from the valley slopes and side valleys is frequent in sections F2 and F6. There is a risk that the stream can only transport WD during floods after intense rainfalls, so the deposition of the woody material is often associated with channel migration. On the lower sections of the watercourse the anthropogenic elements tend to be decisive in the dynamic processes. Right above the fishing ponds the watercourse loses a significant portion of stream power, so the accumulation forms become dominant. Intensive incision can be observed in section F10, where the stream leaving the dams formed steep banks. For the protection of the village the watercourse was regulated on the last two sections. On the lower course (F9-F12) the river bed cannot be regarded as semi-natural. According to the explored hydrogeomorphic properties Váralja stream has some headwater and a few semi-alluvial characters.

Considering the results of our study we conclude that the detailed analysis of other catchments with the presented field survey methodology would be helpful to provide accurate information about the processes and evolution of small streams with various geographical backgrounds. Understanding the large-scale changes occurring during catastrophic periods and exploring the factors influencing the level of vertical erosion and geomorphic evolution of a stream is essential information for the proper management of flash floods increasingly threatening built environments.

\section{Acknowledgements}

The authors are thankful for the colleagues of the Department of Physical and Environmental Geography and Department of Cartography and Geoinformatics at the University of Pécs for their help regarding the field survey. We would like to 
express our gratitude for the Department of Geomorphology at the Jagiellonian University in Cracow for their professional advices on the study. The chief editor, Maria Radoane is also thanked for useful and powerful comments to improve the manuscript. The present scientific contribution is dedicated to the $650^{\text {th }}$ anniversary of the foundation of the University of Pécs.

\section{References}

Angiel M. 1999. Morphodynamic structure of a river channel in a late glacial relief area (Case of the Łeba River, Pomorze Region in the North-Western Poland). Prace Geograficzne 104: 69-107

Benda L, Hassan MA, Church M, May CL. 2005. Geomorphology of steepland headwaters: The transition from hillslopes to channels. Journal of the American Water Resources Association 41(4): 835-851.

Bilby RE, Ward JW. 1991. Characteristics and function of large woody debris in streams draining old growth, clear-cut and second-growth forests in southwestern Washington. Canadian Journal of Fisheries \& Aquatic Sciences 48: 2499-2508.

Chelmicki W, Krzemien K. 1999. Channel Typology For the River Feshie in the Cairngorm Mts, Scotland. Prace Geograficzne 104: 57-68.

Czigany S, Pirkhoffer E, Fabian SA, Ilisics N. 2010. Flash floods as natural hazards in Hungary, with special focus on SW Hungary. Riscuri şi Catastrofe 8(1): 131-152.

Czigany S, Fabian SA, Pirkhoffer E, Varga G. 2011. Flash floods: problems of the small rivers (in Hungarian). In: Schweitzer F. (ed.), Lessons of disasters: strategic research on physical geography, (pp. 155-163). Budapest: Hungarian Academy of Sciences Geographical Research Institute.

Dunkl I. 1992. Fission track evidences on the thermal history and uplift of the Eastern Mecsek Mts. (Hungary): Preliminary results (in Hungarian). Általános Földtani Szemle 26: 163-168.

Galia T, Hradecky J. 2014. Channel-reach morphology controls of headwater streams based in flysch geologic structures: An example from the Outer Western Carpathians, Czech Republic. Geomorphology 216: 1-12.

Gorczyca E. 2007. Morphodynamics of the River Łososina Channel after an extreme flood (Western Carpathian Mountains). Geografija 43(2): 8-15.

Grant GE, Swanson FJ, Wolman MG. 1990. Pattern and origin of stepped-bed morphology in high-gradient streams, Western Cascades, Oregon. Bulletin of the Geological Society of America 102(3): 340-352.

Grecu F, Ioana-Toroimac G, Molin P, Dramis F. 2014. River channel dynamics in the contact area between the Romanian Plain and the Curvature Subcarpathians. Revista de geomorfologie 16: 5-12.

Gyalog L. (ed.) 1996. Legend of the geological maps and brief description of the stratigraphic units (in Hungarian). Budapest: Magyar Állami Földtani Intézet, $171 \mathrm{p}$.

Gyalog L. (ed.) 2005. Short explanatory of map units (in Hungarian). Budapest: Magyar Állami Földtani Intézet.

Haas J. (ed.) 2012. Geology of Hungary. Heidelberg: Springer, $243 \mathrm{p}$.

Halwas KL, Church M. 2002. Channel units in small, high gradient streams on Vancouver Island, British Columbia. Geomorphology 43(3-4): 243-256.

Harvey AM. 2001. Coupling between hillslopes and channels in upland fluvial systems: implications for landscape sensitivity, illustrated from the Howgill Fells, northwest England. Catena 42: 225-250.

HISSTWMD n.d. Online database and map of the Hydrological Information System of the SouthTransdanubian Water Management Directorate. http://ddvir.ddvizig.hu:8000/ddvir/flex/ddvir.html\#

Horvath A. 2005. Meteorological backround of flooding in Mátrakeresztes on April 18, 2005 (in Hungarian). Légkör 50(2): 6-9.

Horvath A. 2015. Analysis of the weather affecting flash floods on 17 of August, 2015 (in Hungarian). Budapest: Hungarian Meteorological Service (http://www.met. hu/ismeret-tar/ erdekessegek_tanulmanyok/index. php?id=1382\&hir=2015._augusztus_17-

i_villamarvizeket_okozo_idojaras_elemzese)

Izmailow B, Kamykowska M, Krzemien K. 2006. The geomorphological effects of flash floods in mountain river channels. The case of the River Wilsznia (Western Carpathian Mountains). Prace Geograficzne 116: 89-102.

Kamykowska M, Kaszowski L, Krzemien K. 1999. River channel mapping instruction. Key to the river bed description. Prace Geograficzne 104: 9-25.

Kaszowski L, Krzemien K. 1999. Classification systems of mountain river channels. Prace Geograficzne 104: 27-38.

Kercsmar Z, Budai T, Csillag G, Selmeczi I, Sztano O. 2015. Surface geology of Hungary. Explanatory notes to the Geological map of Hungary (1:500 000). Budapest: Geological and Geophysical Institute of Hungary

Korpak J. 2007. The influence of river training on mountain channel changes (Polish Carpathian Mountains). Geomorphology 92(3): 166-181. 
Krzemien K. 1981. Zmienność subsystemu korytowego Czarnego Dunajca. Prace Geograficzne 53.

Krzemien K. 1999. Structure and dynamics of the highmountain channel of River Plima in the OrtlerCevedale Massif (South Tirol). Prace Geograficzne 104: 41-55.

Krzemien K. 2003 The Czarny Dunajec River, Poland, as an example of human-induced development tendencies in a mountain river channel. Landform Analysis 4: 57-64.

Krzemien K. 2004. Les transformations contemporaines du lit de la rivière Couze Pavin en Auvergne. Prace Geograficzne 113. (pp. 41-51). Kraków: Institute of Geography of the Jagiellonian University.

Krzemien K, Gorczyca E, Sobucki M, Liro M, Łyp M. 2015. Effects of environmental changes and human impact on the functioning of mountain river channels, Carpathians, southern Poland. Annals of Warsaw University of Life Sciences, Land Reclamation 47(3): 249-260.

Lehmann A. 1995. Geographical field trips in the Mecsek and its surroundings (in Hungarian). Pécs: Janus Pannonius Tudományegyetem, pp. 67-102.

Leopold LB, Maddock T. 1953. The hydraulic geometry of stream channels and some physiographic implications. U.S. Geological Survey Professional Paper 252, $57 \mathrm{p}$.

Leopold LB, Wolman MG. 1957. River Channel Patterns: Braided, Meandering, and Straight. U.S Geological Survey, Washington D.C 39-85. (Professional Paper 282-B).

Loczy D. 2012. Hierarchical presentation of typologies of river channel morphology in international literature (in Hungarian). Földrajzi Közlemények, 136(2): 124-137.

Loczy, Pirkhoffer E, Gyenizse P. 2012. Geomorphometric floodplain classification in a hill region of Hungary. Geomorphology 147-148: 61-72.
Montgomery DR, Buffington JM. 1997. Channel-reach morphology in mountain drainage basins. GSA Bulletin 109(5): 596-611.

OMSZ (Országos Meteorológiai Szolgálat) (2015), Observed national climatic changes (in Hungarian). Budapest: Hungarian Meteorological Service, 8 p. (http://www.met. hu/downloads. php?fn=/metadmin/ attach/2015/10/5427478be32cedd8550dbb035a2257 2f-2015-01-megfigyelt-hazai-eghajlati-valtozasok-vs. pdf)

Peczely Gy. 1979. Climatology (in Hungarian). Budapest: Tankönyvkiadó, 336 p.

Popov JV. 1969. Deformatsyi rechnykh ruseli gidrotekhnicheskoye stroitelstvo. Gidrometeoizdat, Leningrad

Raczkowska Z. 1983. Types of stream channels in the Chochołowska Drainage Basin (The Polish Western Tatra Mts.). Studia Geomorphologica CarpathoBalcanica 16.

Rudberg S, Sundborg Å. 1975. Vattendrageni Norra, Norrland. Geovetenskapliga naturvärden Uppsala Universitet Naturgeografi.

Schumm SA. 1963. A Tentative Classification of Alluvial River Channels. U.S Geological Suvery Circular 477, Washington D.C. 10 p.

Sidle RC, Tsuboyama Y, Noguchi S, Hosoda I, Fujied, M, Shimizu T. 2000. Stormflow generation in steep forested headwaters: A linked hydrogeomorphic paradigm. Hydrological Processes 14(3): 369-385.

Strahler AN. 1957. Quantitative Analysis of Watershed Geomorphology. Transaction of the American Geophysical Union 38: 913-920.

Zingg Th. 1935. Beiträge zur Schotteranalyse. Schweizerische Mineralogische und Petrographische Mitteilungen 15: 39-140. 